\title{
Skiers' expectations as a challenge for managers of protected areas - a case study from the Tatra National Parks in Poland and Slovakia
}

\author{
Joanna Hibner, Jarosław Balon, Miłosz Jodłowski \& Szymon Ciapała
}

Keywords: protected areas, ski resorts, Tatra Mountains

\section{Abstract}

Mountain areas are particularly attractive for the development of winter activities such as skiing, owing to both morphological and climatic conditions. However, mountain areas are at the same time vulnerable. For this reason, they are often under protection. This study focuses on two important and heavily used ski resorts in the Tatra National Parks, Kasprowy Wierch (Poland) and Skalnaté Pleso (Slovakia), looking at skiers' opinions and complaints regarding the resorts. In addition, a comparison between the resorts was conducted. In order to verify the relationship between socio-demographic variables and the skiers' opinions, two types of statistical tests were used: Spearman's rank correlation coefficient and Chi-square. The results show that the Kasprowy Wierch ski resort received a larger number of negative comments than Skalnate Pleso. However, Skalnate Pleso drew more negative opinions regarding the impact of the cable car and ski area on the landscape. The consequences of fulfilling visitors' expectations can be used practically by the managers of the protected areas.

\section{Profile}

Protected area

Tatra Mountain

National Parks

Mountain range

Carpathians

Country

Poland \& Slovakia

\section{Introduction}

Mountain areas are particularly attractive for the development of winter activities such as skiing, owing to both morphological and climatic conditions (slope length and gradient, duration of snow cover; Falarz 2002; Krzan et al. 2002; Holko et al. 2009; Pribullová et al. 2009). Landscape values also play an important role and attract visitors to these areas, not only in the winter season (Pütz et al. 2011). The intensive development of ski resorts has been observed since the mid$20^{\text {th }}$ century, especially in the Alps and other high European mountains, such as the Tatras (Krzesiwo 2015). This has brought many economic as well as social benefits to the local communities (Koenig \& Abegg 1997; Vanham et al. 2009; Tsuyuzaki 1995; Ries 1996; Tsuyuzaki 2002; Watson \& Moss 2004; Braunisch et al. 2011; Morrison \& Pickering 2013; Pröbstl-Haider et al. 2016; Cremer-Schulte et al. 2017; Mayer \& Mose 2017). Managers of ski resorts strive for the continuous development of the resorts (Holden 2000; Krzesiwo 2015; Mayer \& Mose 2017) in order to maximize their profits and to satisfy skiers' needs and goals, such as the availability of good snow conditions, diversification of the ski area, and a choice of ski routes in one ski resort (Gilbert \& Hudson 2000; Dickson \& Faulks 2007; Żemła 2008; Konu et al. 2011; Krzesiwo \& Mika 2011; Dorocki et al. 2014; Nowacki 2016). In the last 20 years, many ski resorts have noted shorter skiing seasons owing to insufficient snow cover (Koenig \& Abegg 1997; Falarz 2002; Krzan et al. 2002; Scott et al. 2003; Abegg et al. 2008; Holko et al. 2009; Vanham et al. 2009; Madziková et al. 2011; Szczerbińska \& Pociask-Karteczka 2015). Artificial snow-making is a common adaptive strategy to climate warming (Hennessy et al. 2008; Steiger \& Mayer 2008; Pütz et al. 2011; Rixen et al. 2011; Steiger 2012).

However, the development of ski resorts is one of the major threats to the conservation of the highmountain environment. Building and maintaining cable cars, ski lifts, ski slopes and trails involves changes in relief and degradation of soil cover: the removal of rock and soil during construction works (to eliminate obstructions on the runs, for example), and changes in geomorphic processes and the physical properties of soil (Fahey \& Wardle 1998; Fahey et al. 1999; Rixen et al. 2003, 2008; Delgado et al. 2007; David et al. 2009; Roux-Fouillet et al. 2011; Ristić et al. 2012). Artificial snow-making as well as slope grooming results in significant changes in water balance: longer presence and greater depth of snow cover on ski slopes, increased water consumption and run-off, and decreased ground-water levels (Berbeka \& Berbeka 2010; RouxFouillet et al. 2011; Rixen \& Rolando 2013). It may also lead to changes in vegetation (e.g. loss of biodiversity) and habitats (Titus \& Tsuyuzaki 1999; Wipf et al. 2005; Caravello et al. 2006; Caprio et al. 2011), and impacts on wildlife (Laiolo \& Rolando 2005; Rolando et al. 2007; Negro et al. 2009). Ski resorts with their related infrastructure and the direct impact of skiers (e.g. noise, littering) are also distinct ecological barriers, causing landscape fragmentation and disturbing migration corridors. The environmental impact of skiing and ski resorts as well as the visual impact of cable cars and ski slopes, perceived as dominant landscape features, have been confirmed by numerous studies in the Tatra Mountains (Mirek 1996; Balon 2002; Guzik et al. 2002; Tylek 2009; Jančura et al. 2009a; Jančura et 


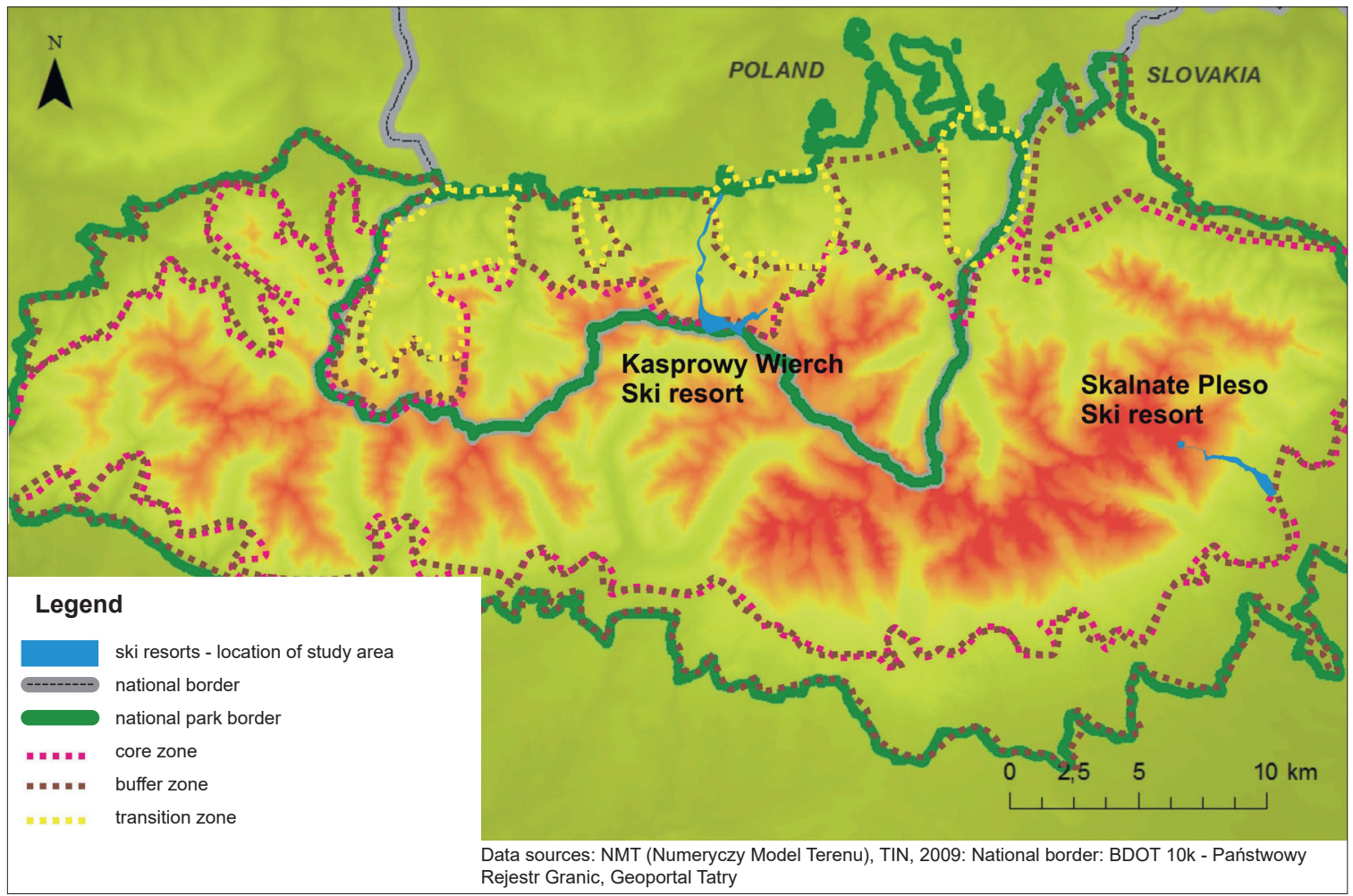

Figure 1 - The study area.

al. 2009b; Raczzkowska \& Kozłowska 2010; Hrčková \& Holubová 2011; Zwijacz-Kozica et al. 2013).

In order to protect vulnerable high-mountain ecosystems from human impact as well as to preserve their environment unaltered or only slightly transformed, a dense network of protected areas has been created in Europe since the beginning of the $20^{\text {th }}$ century, with national parks (NPs) playing the most important role. The development of ski resorts in core zones of NPs is in contradiction with IUCN guidelines and is forbidden by law in most European countries (Dudley 2008; IUCN 2016; Jodłowski 2019). This has resulted in many conflicts between stakeholders in nature conservation (NP authorities, environmental offices, scientists, but also mountaineering organizations) and the ski resort industry (resort operators, local and regional authorities and ski organizations) (Thompson 1999; Holden 2000; Bauch \& Lainer 2014; Krzesiwo 2015; Mayer \& Mose 2017). Although the establishing of NPs in the Alps (e.g. Hohe Tauern in 1981, Berchtesgaden Alps in 1978 see Pichler-Koban \& Jungmeier in 2017) restricted the development of ski resorts in the areas with the highest bio- and geodiversity, cable cars, ski lifts and ski slopes were often located in the close vicinity of protected areas. However, in the Carpathians and the Sudetes, the high-mountain ranges are relatively small and present a unique value in their respective countries. In these two areas, the NPs encompass most of the area above the timberline. Therefore, the development potential for the ski resort industry is very limited there. In most cases, in the high mountains of Poland, Slovakia and Czechia the cable cars and ski runs were built before the NPs were established, and the creation of protected areas has slowed down their development (Krzesiwo 2014, 2015; Jodłowski 2019).

The challenges for the operators of ski resorts located within the protected areas encompass legal constraints, over-exploitation of the natural environment as a result of artificial snow-making (decreasing water supplies), together with growing economic costs. This could in future lead to a decline in the resorts' competitiveness on the market. Thus, change in the ski-resort development paradigm and reassessment of earlier adaptive strategies relating to climate warming in close co-operation between ski-resort operators, the local authorities and managers of protected areas is necessary (Flagestad \& Hope 2001; Steiger \& Mayer 2008; Pütz et al. 2011; Rixen et al. 2011). Such a paradigm change is particularly relevant for NPs in Central and Southern Europe, where the conflict between nature conservation and the development of ski resorts is particularly marked (Jodłowski 2019).

One way to reduce the negative environmental impact of tourism, including skiing, is the introduction of restrictions, in terms of infrastructure construction and development, as well as of visitors' mobility. However, the results from many protected areas show that the regulations and limitations introduced by their managers are broken by tourists because of a lack of understanding of their legitimacy (Eagles et al. 2002; Witkowski et al. 2010; Spenceley et al. 2015; Bielański et al. 2017; Jodłowski 2019). Only increasing visitors' environmental awareness through campaigns 
Table 1 - Cable cars and ski runs in the Kasprowy Wierch and Skalnaté Pleso ski resorts (based on: Kasprowy Wierch 2017a; Kasprowy Wierch 2017b; Vysoke Tatry 2017a; Vysoke Tatry 2017a).

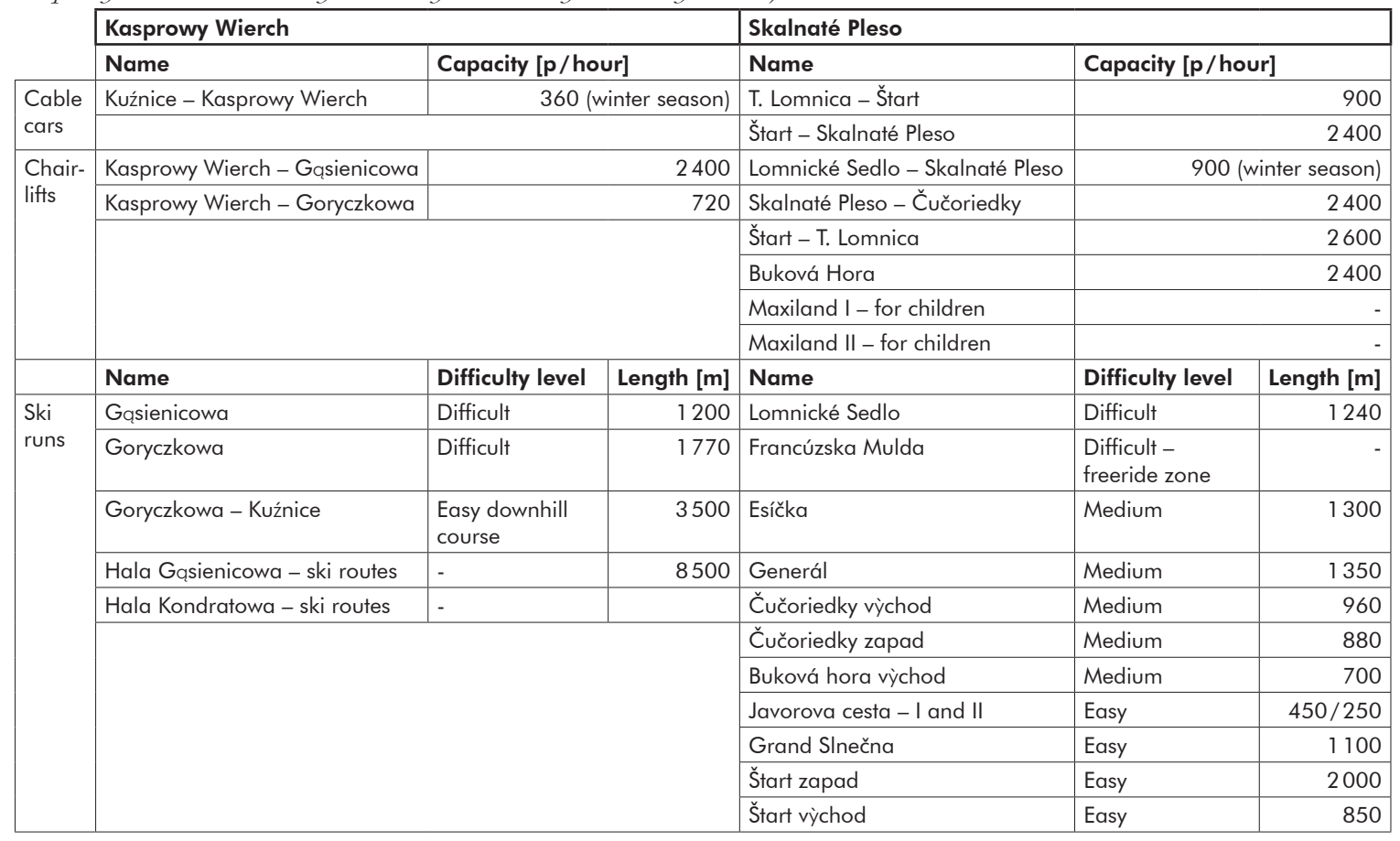

which promote environmentally-friendly behaviour brings positive results. Additionally, it is important to take into account the opinions of various stakeholders, both managers of protected areas and entrepreneurs, and visitors who are interested in practising specific winter sports (Eagles et al. 2002; Sterl et al. 2010; Imoos \& Hunziker 2015; Cremer-Schulte et al. 2017; Jodłowski 2019).

The main aim of this study is to gain information on skiers' expectations and criticisms regarding two important ski resorts in the High Tatras: Kasprowy Wierch (Poland) and Skalnate Pleso (Slovakia). A further aim is to examine whether the fulfilment of skiers' expectations could have negative consequences for the environment. The article also includes recommendations for how to meet skiers' expectations without significant impact on the natural environment. An additional aim is to compare the two ski resorts.

\section{Study area}

Both ski resorts are located in the Tatra Mountains - the highest mountain range in the Carpathians, on the border between Poland and Slovakia (Figure 1). The whole area is protected within NPs (Poland's Tatrzański Park Narodowy (TPN) and the Slovakian Tatranský Národný Park (TANAP). The protective regimes and regulations regarding tourism management in both parks differ significantly. However, in both it is forbidden to leave marked trails or ski outside designated trails and slopes (TANAP 2019; TPN 2019; Jodłowski 2019). Since 1993, both parks together have been protected as a single UNESCO Bio- sphere Reserve, and since 2004 as Natura 2000 sites (PLC120001, SKCHVU030, SKUEV0307).

TPN (211.97 $\left.\mathrm{km}^{2}\right)$ was established in 1954 and is visited by a vast and growing number of tourists (approximately 2.75 million between 2000 and 2010, 3.7 million in 2016, and 4.0 million in 2018; Tatrzański Park Narodowy 2018). Approximately $14 \%$ of visits took place during the winter season. The authors have not been able to obtain specific data on the number of skiers among winter visitors to Kasprowy Wierch $(\mathrm{KW})$, but the majority of winter visits are connected with skiing (Taczanowska et al 2019; TPN 2019; TPN STATISTIC 2019). TANAP was established in 1949 and has more than three times the area of TPN $\left(738 \mathrm{~km}^{2}\right)$. There are no entrance fees to TANAP, nor any other systematic register of visits, and so there are no detailed annual data on the number of visitors, which is roughly estimated at 3.5 million (Šturcel \& Švajda 2005; Švajda 2009; TANAP 2019). Around $45 \%$ of tickets for cable cars to the Skalnate Pleso (SP) area were bought during winter seasons. However, as for the KW area, the authors have not been able to obtain specific data on the number of skiers among winter visitors.

The cable car from Kuźnice (Zakopane) to KW (1949 m a.s.l.) was built in 1936, despite opposition from organizations connected with the protection of nature and those involved in tourism and mountaineering (Konieczniak 2010). The cable car and the resort were owned by a public company until 2013, when KW ski resort was sold to a private enterprise founded by an international investment fund. Since 2018, the resort has again been under the management 
of a public company, owned by the State Treasury. In the 1960s, two additional chairlifts were built, which extended the opportunities for skiing in the area. Altogether, there are $15 \mathrm{~km}$ of runs, of which less than $3 \mathrm{~km}$ are located above the timberline. The rest are relatively narrow ski runs and trails in the forest (Table 1; Skawiński 2005; Laszczyk et al. 2007; Kasprowy Wierch 2017a). The whole area of KW ski resort (excluding the buildings of the upper cable car station) is located in a zone of strict nature protection (the highest protection regime in Poland). However, it is also designated as the buffer zone of the UNESCO Biosphere Reserve. Despite numerous discussions, artificial snow-making is not allowed there (Nowacki 2016), and slope grooming is conducted only in one part of the area designated for skiing. Skiers do not have to pay any additional entrance fee to the NP; this is included in the ski pass price.

The first cable car from Tatranska Lomnica to Lomnický štít (2632 m a.s.l.), with a mid-station at SP, was built in 1938 and caused public protests, especially from conservation groups (Muntág 2007; Bohuš \& Bohuš 2008). An additional chairlift to Lomnické sedlo (2190 m a.s.l.) was built in 1957. Since 2009, SP ski resort has been owned by one of the biggest tourism companies in Central Europe - Tatra Mountain Resorts (which also owns Jasna ski resort in the Nizke Tatry NP in Slovakia, and the Špindlerův Mlýn ski resort in the Krkonoše NP in Czechia). There are $12.4 \mathrm{~km}$ of ski slopes and ski trails available for skiers (Table 1; Vysoke Tatry 2017a). The SP resort is mostly located in the core zone of the UNESCO Biosphere Reserve as well as within the Skalnatá Dolina national nature reserve. Only the lower part of the slopes is located in the buffer zone of the Biosphere Reserve.

In November 2004, over 12000 ha of montane forest in the Tatras were flattened by strong wind (the so-called Vel'ká kalamita; Balon \& Maciejowski 2005). Since this natural disaster, the whole of SP ski resort (as well as the other ski resorts in TANAP which do not have windbreaks) has been excluded from the $\mathrm{Na}$ tura 2000 site. This made the extension of ski runs and the modernization of ski lifts possible. It also raised numerous protests, including objections from the IUCN (Švajda 2006; TATRA MAB 2019). Currently, all the runs in the ski resorts are groomed, and snow-making takes place on $86 \%$ of them, mostly in the lower parts (Nowacki 2016).

$\mathrm{KW}$ and SP are the most popular ski resorts in Poland and Slovakia, with only a few competitive resorts in the high-mountain area: Chopok-Jasna in the Nizke Tatry NP, and Vratna in the Mala Fatra NP in Slovakia; Szrenica in the Karkonosze NP in Poland. In TANAP, there are three ski resorts in addition to SP (Štrbské Pleso, Roháče and Hrebienok); however, SP is the highest ski resort in Slovakia. There are also a few ski resorts near Zakopane (Poland), in the mid-mountain area outside the NP. The best of these is Białka Tatrzańska, a well-developed modern ski resort. However, the upper station is located 1000 metres lower than in $\mathrm{KW}$, which is therefore often preferred by skiers (Krzesiwo 2014; Nowacki 2016).

\section{Methods}

An on-site survey (Paper-and-Pencil Interviewing technique (PAPI)) was conducted by skilled interviewers in the two cable car areas to gather data using a non-random, accidental sampling method. The survey was conducted in the winter seasons 2013/2014 and 2014/2015. A total of 404 questionnaires were collected (KW: 197; SP: 207). The questionnaire was divided into four thematic sections: (I) general information about the trip; (II) motivations; (III) opinions; (IV) mountain experience and safety. Additionally, general information about the respondents was collected. One of the purposes of the surveys was to obtain visitors' opinions about particular ski resorts as well as about ski trail preparations. Respondents were also asked for their opinions on the number of people carried by the cable cars, and on the visual impact of the cable car and ski area on the mountain landscape. All the questions were based on a 5-point Likert scale (Babbie 2003). Respondents who were less satisfied with their visit to a particular ski resort (3 points or less on the Likert scale for general opinions about the ski resort and/ or ski trail preparations) were also asked to explain their dissatisfaction. At KW, 67 visitors submitted 111 comments; at SP, 53 visitors submitted 83 comments. In the next step, statistical analyses using SPSS software were conducted. In order to verify whether there was any relationship between skiers' opinions and criticisms regarding selected ski resorts on the one hand and socio-demographic variables on the other, two types of statistical test were used: Spearman's rank correlation coefficient (rS) and Chi-square.

\section{Results}

Opinions about the ski resorts

More than half of the respondents (KW: $53 \%$; SP: $57 \%$ ) declared that the cable car capacity was adequate. Therefore, they did not wish to see any changes. However, around $20 \%$ of the respondents from KW believed that the cable car's capacity should be increased. Only a small percentage of respondents stated that cable car capacity should be reduced (KW: 10\%; SP: $8 \%$; Figure 2). According to the majority of respondents (KW: 70\%; SP: 64\%), the cable cars fit well with the mountain landscape. About $12 \%$ of respondents believed that the cable cars in SP did not go well with the landscape (Figure 3).

The results show that only about half of the respondents evaluated KW ski resort as either good or very good ( $35 \%$ and $17 \%$ respectively). The trend is reversed in SP, where almost $90 \%$ of visitors felt satisfied with their visit (Figure 4). The more negative feelings about KW were probably the result of a 


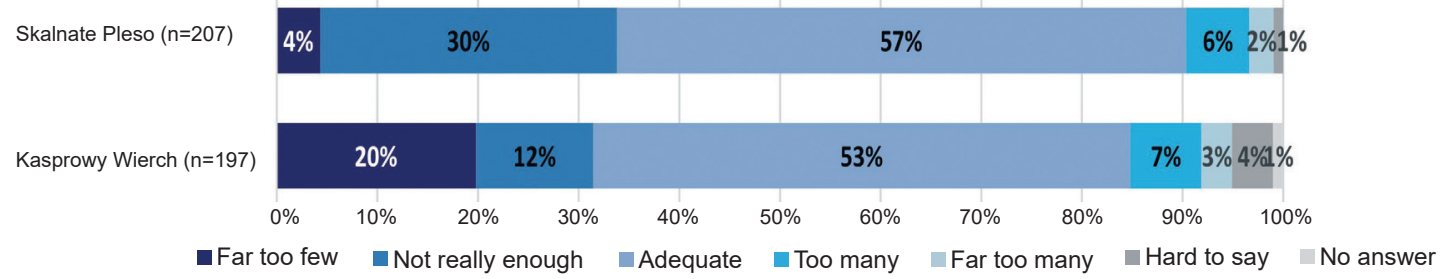

Figure 2 - Opinions about the number of people carried by the cable cars.

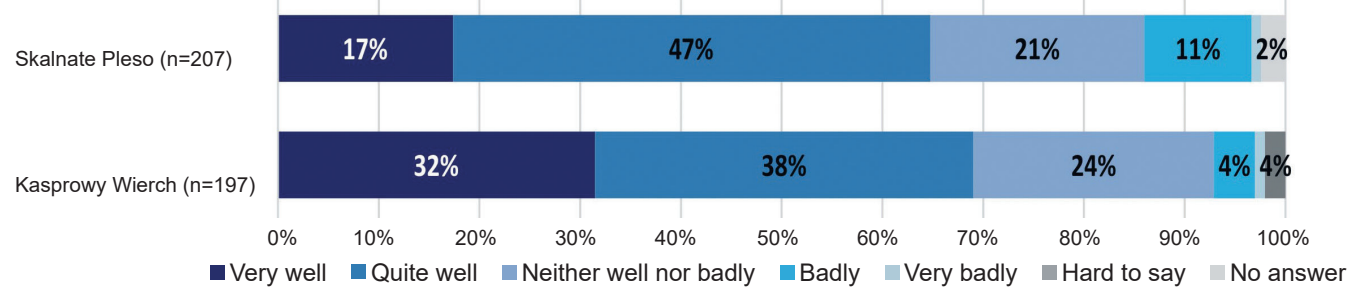

Figure 3 - How the cable cars fit into the landscape, according to respondents.

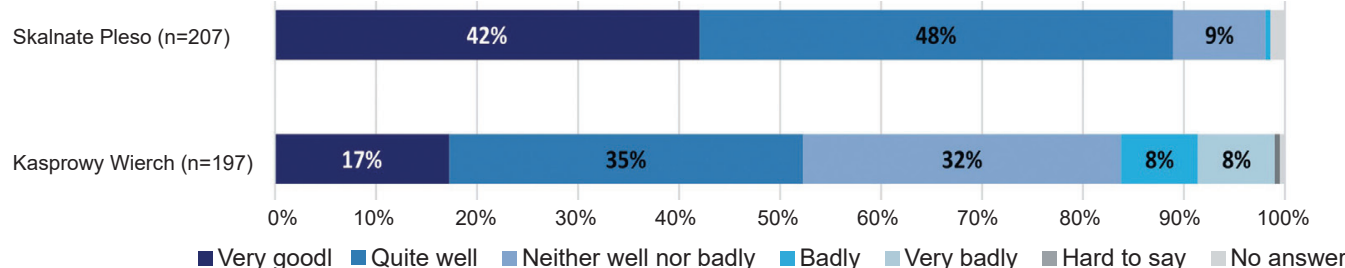

Figure 4-Opinions about the ski resorts.

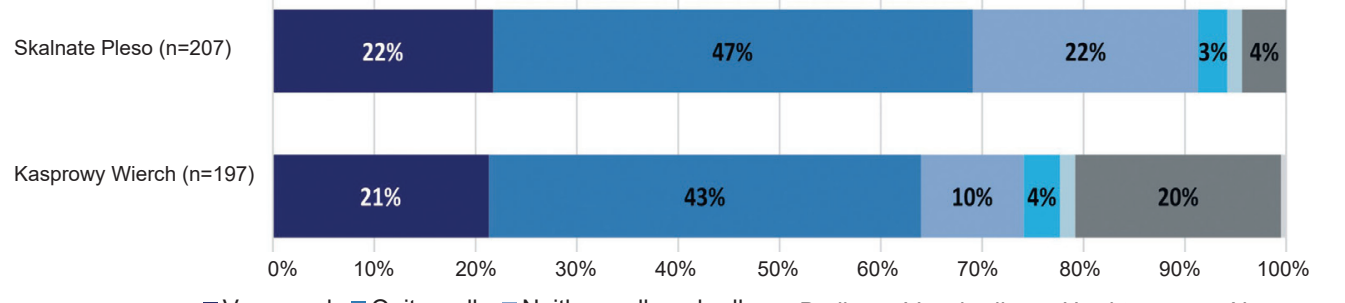

घery good $\square$ Quite well $\square$ Neither well nor badly $\square$ Badly $\square$ Very badly $\square$ Hard to say $\square$ No answer

Figure 5 - Opinions about the preparation of the ski trails.

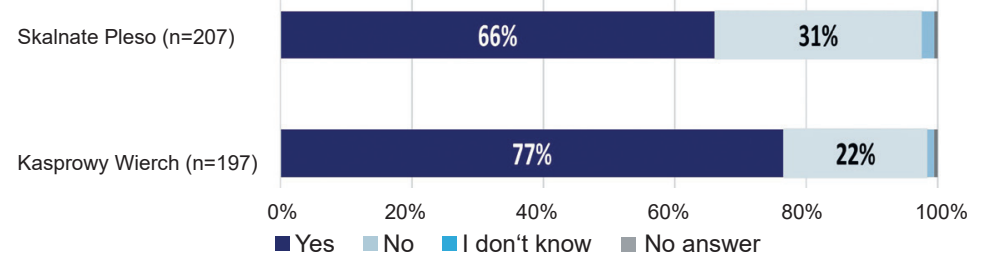

Figure 6 - Should new cable cars / chairlifts be built in the research area? - Respondents' opinions.

comparison with other ski resorts in the Alps and Slovakia which have modern infrastructure and greater skiing opportunities. However, the criticism of $\mathrm{KW}$ could also reflect a negative attitude towards the cable car managers, because prices were often thought to be too high in comparison to the quality of service, as emerged in discussion with visitors. A slightly different trend was observed regarding the preparation of ski trails. In both resorts, about $60 \%$ of respondents considered it good or very good (Figure 5).

The majority of respondents accepted development of the ski resort, including the building of new cable cars. However, some differences between ski resorts were observed. Approximately $77 \%$ of respondents from KW stated that new cable cars and chairlifts should be built in TPN. Slightly fewer respondents $(66 \%)$ supported building new cable cars in TANAP (Figure 6).

\section{Complaints regarding the ski resorts}

Complaints were divided into four categories:

1. comments on the preparation of the ski trails,

2. comments on new investments within the resorts,

3. socio-economic comments, 


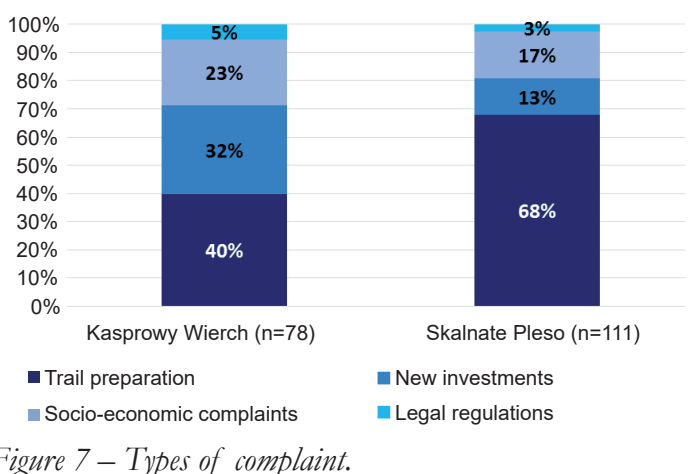

4. comments on the legal regulations (which are different in the two resorts).

The results differ slightly between the two resorts - primarily, a greater number of comments by visitors to KW, where 111 comments made by 67 visitors, compared to 83 comments from 53 respondents at SP.

In $\mathrm{KW}$, where snow-making is forbidden, approximately $40 \%$ of complaints concerned the preparation of the ski slopes, especially the need to maintain acceptable snow cover. A few respondents (3\%) requested the opening of all ski trails (there are frequent problems with chairlift operation on Goryczkowa ski trail due to strong wind, where there is also at times insufficient snow cover). Individual comments also concerned the extension and presence of obstructions on the trails ( $1 \%$ and $2 \%$ of respondents respectively). $32 \%$ of all responses concerned new investments. Approximately $10 \%$ of respondents suggested the modernization of the chairlift at the Goryczkowa ski trail. Some respondents also wanted to see an increase in the number of ski trails (3\%), the construction of new chairlifts $(2 \%)$, and increased capacity of the existing chairlifts $(2 \%)$. Individual respondents suggested also increasing the speed of the chairlift, and the demolition of the old hut in the valley. $23 \%$ of comments referred to socio-economic questions. The majority of complaints within this category concerned excessive prices ( $8 \%$ of all responses). Other comments referred to improving the ticket sales system, generally improving the quality of service, enriching the gastronomic offer, and restoring the old historical restaurant decor. Respondents also asked for improvement in the punctuality of the chairlifts (the main cable car should run every 10 minutes during high winter season) and free maps. Some visitors complained about crowding on the ski slopes. $5 \%$ of responses dealt with legal regulations, suggesting that a freeride zone might be introduced there $(3 \%)$ (i. e. an area for free, even extreme, skiing), and changes near the start of the Goryczkowa trail (1\%; Figure 7$)$.

Criticisms in SP were more homogeneous. Approximately $68 \%$ of comments concerned the preparation of the ski trails, notably the need to improve the quality of snow grooming (16\% of all respondents). Comments also concerned bumps and protruding rocks $(7 \%)$, the extension of trails, and improving trail marking (1\%). Approximately $17 \%$ of negative comments made in SP were of a socio-economic nature. Respondents complained mainly about crowding on the ski slopes and high prices, and the need to improve the ticket sales system, the quality of service, and the gastronomic offer. Only 13\% of comments concerned new investments - for example, modernization of the old chairlift to Lomnické sedlo (3\%), increasing the number of ski trails and chairlifts, and demolition of the old unused cable car buildings (1\%). Only 3\% of all comments considered legal regulations. Respondents argued for lifting the ban on ski-touring on ski runs after 4:00 p.m. (Figure 7).

In order to obtain information about the relationship between opinions and complaints on the one hand, and other socio-demographic variables, Spearman's rank correlation coefficient $(\mathrm{rS})$ and $\mathrm{x} 2$ test (Pearson's chi-squared test (x2); Table 2) were used. The results of the rS show that there are only weak negative correlations between (1) opinions on the ski resort and the frequency of stay in SP during the skiing season $(-0.2)$, and (2) opinions on the preparation of ski trails and the frequency of stay in the Tatra Mountains outside the skiing season ( -0.225$)$. A negative correlation in these cases means that respondents who were less likely to ski in SP or to visit the Tatras outside the skiing season evaluated the preparation of the ski trails negatively.

The results of the $\mathrm{x} 2$ test show the following correlations: (1) between respondents' type of activity in the ski resorts, their opinions on the number of persons carried by cable cars, and their opinions on the ski trails; (2) between the respondents' type of activity in the ski resorts and their opinions about building new cable cars in KW; (3) between frequency of stay in the ski resorts during the skiing season, their general opinions on these specific ski resorts, and their opinions on the preparation of the ski trails; (4) between complaints and opinions about ski resorts, as well as opinions on the preparation of the ski trails for both SP and KW. However, for the majority of the complaints, there were poor data distributions, which means that too many cells had an expected number of less than 5 (Table 2).

\section{Discussion}

\section{Comparison with other studies}

As this research shows, good snow conditions on the ski slopes are the most important factor affecting respondents' satisfaction levels. Similar conclusions can be found in other research (Dickson \& Faulks 2007). Gilbert \& Hudson (2000) emphasize that the lack of good snow conditions and crowding on the slopes discourage visitors, even those skiers who to date have been very active. Konu et al. (2011) note that good snow conditions as well as the diversification of the ski area are among the most important factors 
which determine respondents' choice of ski resort. It is worth emphasizing that the main objection in both research areas was the inadequate preparation of ski trails in terms of snow cover.

The majority of other studies include a wider range of elements used to assess ski resorts. Nevertheless, there are similarities between our findings and those of other researchers. Dorocki et al. (2014) also showed that ticket prices were important: in their study area in the Podhale region of the Carpathians, ski resorts with lower-priced tickets were highly rated. In the Czech region of Beskydy (Havrlant 2011), slightly different criticisms, relating mostly to complementary services in ski resorts, were made by respondents. The overall level of satisfaction was similar in our research.

Similar research was conducted by Krzesiwo \& Mika (2011) in the Silesian Beskids as well as in the Podhale region. However, they included wider and more detailed elements when assessing skiing conditions. Their results showed that the relatively new, modern ski resort in Białka Tatrzańska (Podhale region), which is close to the Tatra NP, is evaluated much more highly than either of the ski resorts analysed in the present study. The main objections concerned over-crowding.

Interesting research has also been conducted in Tyrolean ski resorts by Pröbstl-Haider et al. (2016). Their work was not intended to assess the ski infrastructure, but to analyse opinions on the potential reduction in size of the protected areas in order to expand the ski resorts. A similar question was also asked in this research ("Should new cable cars / chairlifts be built in the research area?'). If we compare the results from our own and Pröbstl-Haider et al.'s studies, we note that substantially more respondents from the Tyrolean ski resorts than in KW were opposed to further expansion of the resort. However, in the Tyrolean research, the authors emphasized that further expansion could take place only by limiting the protected area. Similar results were noted when comparing the Tyrolean ski resorts and SP.

Nowacki (2016) compared Polish, Czech and Slovak ski resorts using the hedonistic pricing method. The results showed that KW definitely does not represent good value for money. Similar objections were made by respondents from KW in this research. Furthermore, according to Nowacki (2016), the best ski resort among all the Polish, Czech and Slovak resorts is located in SP.

\section{Implications for PA management}

One of the key objectives for managers of protected areas is to reconcile preserving the natural and cultural values of an area with enabling its recreational use. This could be achieved either by enforcing legal regulations or through direct and indirect soft management measures (Eagles et al. 2002). The legal regulations on a national level concerning the recreational use of NPs in Poland and Slovakia are relatively strict compared with those in Alpine countries. Not only is it forbidden to build any infrastructure which may cause a threat to the natural environment, but there are also far-reaching limits on mountaineering, climbing and skiing (both ski-touring and alpine skiing) (Jodłowski 2019). Thus, the possibility of fulfilling skiers' expectations concerning both the current functioning of the ski resorts in the Tatra Mountains as well as proposed changes must take into account economic, social and environmental factors, as well as current legal regulations.

The recurring ideas for the development of ski resorts in the Tatra Mountains (new cable cars, chairlifts, and an expanded network of ski runs and trails), even if they might be economically viable, must be strongly rejected because of their potential environmental impact. In Poland, such developments are almost impossible to carry out owing to regulations on Natura 2000 sites concerning nature conservation and environmental impact (Ustawa 2004; Ustawa 2008). In Slovakia, such plans are more feasible, since ski resorts were excluded from Natura 2000.

Old infrastructure in poor condition not only requires proper maintenance and repair works, but strongly affects visitors' satisfaction. Such infrastructure may also pose safety and environmental threats (noise, soil pollution). This is the case mainly for the Goryczkowa chairlift in KW. Thus, modernization is necessary, although it should be limited to replacing the old chairlift with a new one without increasing its capacity and length (which are in the plans of the ski resort's operator).

Owing to its environmental impact, artificial snowmaking is one of the most controversial matters in relation to ski resorts. However, it is carried out, to varying extents, in almost every ski resort in Europe, as well as in the NPs in Slovakia (including the Tatra NP) and Czechia, and in Karkonosze NP in Poland. In the Polish Tatra NP, it is forbidden under the terms of the environmental permit, which also regulates other aspects of infrastructure, such as the start of the skiing season (Jodłowski 2019). The tendency to use artificial snow on the slopes will probably get stronger, in view of a warming climate. The limited natural water sources in the Tatra Mountains (Kot 2010) and increased water demand in winter will eventually lead to the construction of reservoirs and a piping system. Such works would require the use of heavy equipment and cause largely unpredictable environmental damage. Cautious slope grooming as well as snow gathering on leeward slopes and its relocation might be a solution for lack of snow cover in the most sensitive parts of ski trails, although it will not solve the problem in the long term. Therefore, we recommend that artificial snow in NPs should be avoided or at least minimized, even if this leads to decreasing ski resorts' incomes due to a shorter skiing season.

However, the results show that further development of ski resorts in the Tatra Mountains is generally accepted by their users, with a high level of acceptance 
Table $2-\times 2$ test - respondents' opinions analysed in terms of sociodemographic and characteristic variables of visit. (*) but poor data distribution

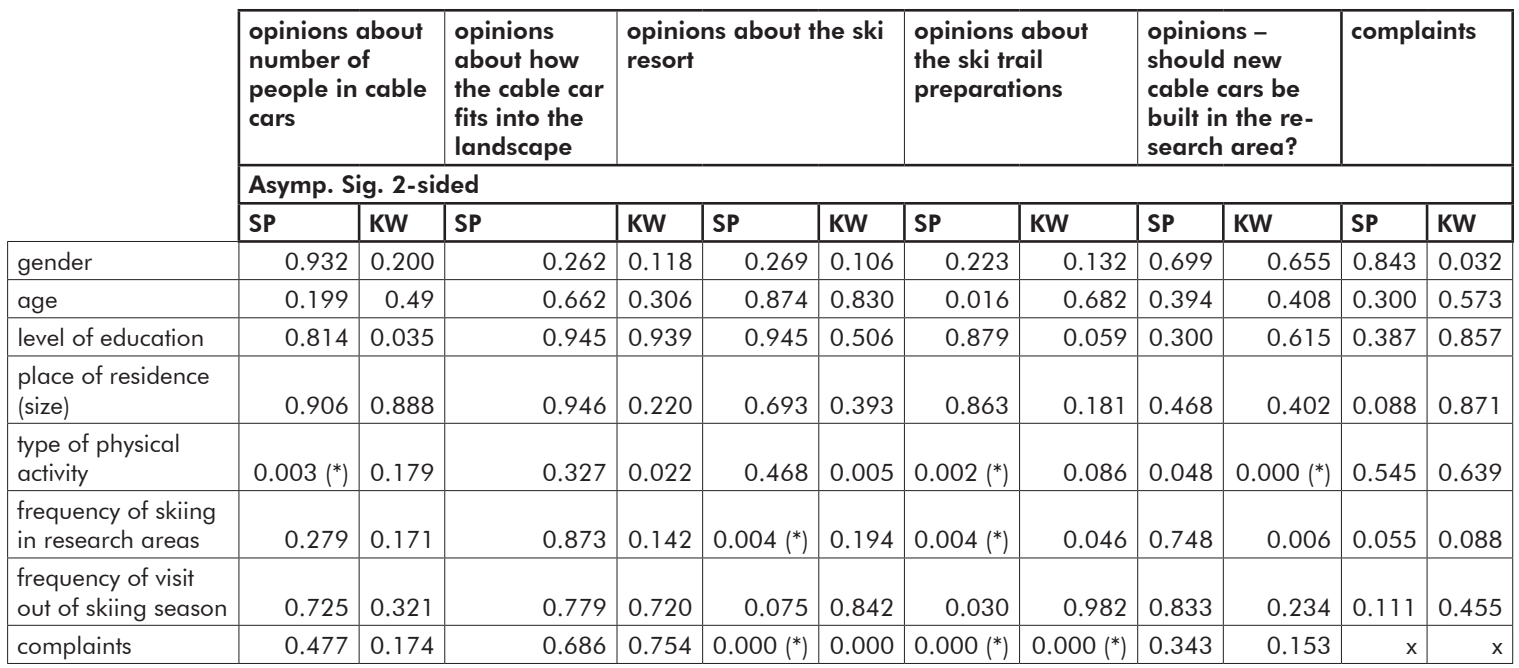

of artificial snow-making as well. Additionally, most respondents do not perceive the skiing infrastructure as a factor that decreases landscape value. Thus, a management strategy that limits the use of artificial snow might be considered unsympathetic towards skiers and ski resorts. Hence, an educational campaign raising environmental awareness, but also promoting ski resorts in the Tatra Mountains as environmentally friendly, is needed, pointing to the unique opportunities for skiing in pristine high-mountain landscapes on natural snow.

Educational campaigns, however, are hard to implement without the close co-operation of stakeholders. Managers of NPs, environmental offices, scientists, ski-resort operators, the skiers themselves and tourism organizations are all crucial to ensure the effectiveness of any campaign. In 1996, one such broadranging campaign aimed at ski tourers (Skibergsteigen umweltfreundlich) was launched in the German Alps by the German Alpine Association (DAV) together with the Bavarian environmental office. After running for almost 20 years, it was expanded to address other outdoor activities in the mountains (Deutscher Alpenverein 2014). In the Polish Tatra Mountains, a few educational campaigns have been launched in recent years focusing mostly on wildlife protection and addressed to all NP visitors (Jodłowski 2019). In order to reach skiers specifically, the buildings of cable car stations might be partially adapted as visitor centres, which would also enforce close co-operation between ski resort operators and NP managers. Such projects are being carried out in the Berchtesgaden NP (Germany) and the Sierra Nevada NP (Spain), where higher cablecar stations (Jenner and Hoya de la Mora) are located on the NPs' borders (Jodłowski 2019).

A strategy of this type might be effective in the Polish NP, where KW is not perceived by Poles as a typical ski resort but as the Holy Mountain for Skiers - a historical, almost legendary place (Nasz Kasprowy 2018).
The designation of freeride zones (without grooming and artificial snow-making) in the vicinity of existing ski slopes, and relaxing restrictions for ski-touring would be part of the strategy. However, such ideas are controversial because of the possible impact on wildlife (Thiel et al. 2008; Bielański 2010; Zwijacz-Kozica 2008; Zwijacz-Kozica et al. 2013). Detailed regulations would need to be drawn up, followed by improving ski slopes and ski trails, and an informational and educational campaign.

Another suggested management strategy is place demarketing (Kern 2006; Wearing et al. 2007; Bradley \& Blythe 2013; Koniorczyk \& Wiechoczek 2014), which would lead to a reduction in the number of ski resort users in NPs and changing their social profile. The technical difficulties of ski slopes in a high-mountain environment should be underlined in the marketing policy of both NPs and ski resorts to discourage inexperienced skiers. At the same time, outside NPs, other ski resorts, with easier ski runs and modern infrastructure, should be developed and promoted along with other outdoor activities and tourist attractions. Although demarketing strategies as such based on economic tools (e.g. higher ticket prices) are rarely used in European NPs, a combination of informational and place demarketing is quite common, even if it is not called such - for example, giving information about current weather and snow conditions as well as the difficulties of particular trails in order to discourage less experienced tourists (Eagles et al. 2002; Jodłowski 2019). Demarketing strategies are also used in combination with direct regulations (legal restrictions).

The Hauts-Plateaux du Vercors nature reserve (French Alps) is promoted as a wild area unsuitable for inexperienced visitors. Cross-country skiing and ski touring (especially guided tours) are preferred activities, but investments in ski resorts are not allowed (Dupuis 2004). In Gesäuse NP (Austria), special zones (Winterrubezone) were established in 2007 to protect 
the winter habitats of galliforms (Tetrao urogallus and Lyrurus tetrix), which were threatened by ski touring. In order to reinforce formal restrictions, NP managers promote nature-friendly winter activities outside these zones through educational tools, also creating ski trails that bypass threatened habitats (Sterl et al. 2010).

In Tatra NP, no such strategies have been implemented so far. However, in the Polish Tatra NP, a small but successful campaign has been launched recently to protect Crocus scepusiensis, a charismatic species found in mountain pastures in the Western Carpathians, threatened by massive trampling. NP managers and local authorities not only use various media as well as repressive measures to discourage tourists from visiting meadows in the NP, but also promote visiting similar locations outside the protected area (TPN 2018).

\section{Strengths and weaknesses of the research}

An important strength of this research is the selection of the ski resorts included in the analysis. Both ski resorts are located in the same mountain range. Furthermore, the historical development of both started in the 1930s, and both KW and SP are protected as NPs. However, the protection regimes in the two parks and the extent of restrictions are different, which is a result partly of political and economic pressure. Therefore, despite a similar historical development, the ski resorts have developed in distinct ways. Thus, their perception by tourists also varies.

This research does not include a detailed assessment of the elements affecting the perceived quality of a ski resort, which limits the possibility of comparing our results with other studies. A further significant limitation of this research was the absence of a specific question to identify the resorts' weak points. Comments on this were limited to those made by respondents who were less satisfied with their visit to a particular resort. It would also be worthwhile asking respondents about the strengths of the ski resorts, and about their knowledge and awareness of protected area status and regulations.

\section{Conclusions}

The KW ski resort was definitely less favourably evaluated by visitors. A higher percentage of respondents evaluated both the cable car capacity and the overall functioning of the resort as very poor, and reported what they considered to be necessary changes. These comments related mostly to the limited number of cable cars and chairlifts operating in KW. Significantly fewer ski trails compared to the SP ski resort and prices that do not reflect the limited offer and quality of service also had a negative impact on the general opinions about KW. However, KW was more favourably assessed in terms of how well it sits in the surrounding mountain landscape. This is related to the fact that SP offers more ski trails and chairlifts, and hence its impact on the environment is greater and more visible.
A similar correlation is noted when it comes to the comments about the construction of new chairlifts. Respondents from SP were less willing to accept the idea of building new chairlifts, because the existing ski resorts on the Slovak side of the Tatra Mountains are considerably more developed. The investor (TMR the owner of SP ski resort) presented a project for a new cable car, which would have connected the SP and Hrebeniok areas, but the project was rejected owing to social protests (Portal Tatrzański 2019).

SP, with its extensive offer, does not significantly differ from the standards of Alpine ski resorts. The majority of skiers in SP were satisfied with their visit, and complaints here concerned mainly technical issues related to the maintenance of the ski trails. The implementation of further restrictions in the functioning of the ski resort, although a reasonable management strategy concerning environmental factors, is unlikely owing to political and economic pressure. Thus, management actions should be aimed at limiting the expansion of the ski resort (Portal Tatrzański 2019).

Compared to other modern ski resorts, KW is poorly developed and attracts mainly local visitors. According to the results (respondents' opinions and criticisms), in order to reach the standard of another Tatra resort, SP, KW should implement many far-reaching changes, which would have a significant impact on the natural environment.

From the skiers' point of view, expanding the KW resort would be the proper strategy. This would undoubtedly raise its standard to that prevailing in Alpine ski resorts. However, such investment is not only in strong contradiction with the general concept of a NP, but also impossible to implement according to Polish law. Management strategies that we recommend could change the quantitative and qualitative structure of skiing activity in the NP, minimizing its environmental impact, and raising ecological awareness and support for nature conservation strategies. The crucial factor in implementing such strategies is close co-operation between the various interest groups, with NP managers and local authorities being key stakeholders who, in an optimal scenario, would share the ownership of cable cars and ski lifts. Such changes in the ownership structure are currently a subject of political debate (Portal Samorządowy 2017).

\section{References}

Abegg, B., R. Bürki, H. Elsasser 2008. Climate change and tourism in the Alps. In: Borsdorf, A., J. Stötter \& E. Veulliet (eds.), Managing alpine future. Wien: 73-80.

Babbie, E. 2003. Badania spoteczne w praktyce. Warszawa. [In Polish]

Balon, J. 2002. Regionalne zróżnicowanie konfliktów człowiek-środowisko na obszarze Tatrzańskiego Parku Narodowego. In: Partyka, J. (ed.), Uìytkowanie turystyczne Parków Narodowych. Ruch turystyczny - zagosp- 
odarowanie - konflik.ty - zagrożenia: 715-722. Ojców. [In Polish]

Balon, J. \& W. Maciejowski 2005. Wpływ huraganowego wiatru z dnia 19 listopada 2004 na krajobraz południowego skłonu Tatr. In: Szponar, A. \& S. Horska-Schwarz (eds.), Problemy Ekologii Krajobrazu. Struktura przestrzenno - funkecjonalna krajobrazu 17: 92100. Wrocław. [In Polish]

Bauch, K. \& F. Lainer 2014. The untamed high mountain area of Hohe Tauern National Park. eco.mont - Journal on Protected Mountain Areas Research and Management 6(1): 35-44.

Berbeka, J. \& K. Berbeka 2010. Wpływ ocieplenia klimatu na działalność alpejskich ośrodków narciarskich. Folia Turistica 22: 133-146. [In Polish]

Bielański, M. 2010. Ruch narciarzy wysokogórskich w Tatrzańskim Parku Narodowym. Folia Turistica 22: 185-207. [In Polish]

Bielański, M., P. Adamski, S. Ciapała \& M. Olewiński 2017. Poza szlakowa turystyka narciarska w Tatrzańskim Parku Narodowym. Turystyka w lasach i na obszarach prayrodniczo cennych. Studia i Materialy CEPL w Rogowie 19(3): 45-52. [In Polish]

Bohuš, I. \& I. jr. Bohuš 2008. Premeny Tatranských osád. Tatrzańska Łomnica. [In Polish]

Bradley, N. \& J. Blythe 2013. Demarketing. LondonNew York.

Braunisch, V., P. Patthey \& R. Arlettaz 2011. Spatially explicit modeling of conflict zones between wildlife and snow sports: prioritizing areas for winter refuges. Ecological Applications 21(3): 955-967.

Caprio, E., D.E. Chamberlain M. Isaia \& A. Rolando 2011. Landscape changes caused by high altitude ski-pistes affect species richness and distribution in the Alps. Biological Conservation 144: 2958-2967.

Caravello, G., E. Crescini, S. Tarocco \& F. Palmeri 2006. Environmental modifications induced by the practice of "Artificial snow-making" in the Obereggen/Val D'Ega Area (Italy). Journal of Mediterranean Ecology 7: 31-39.

Cremer-Schulte, D., M. Rehnus, A. Duparc, C. Perrin-Malterre \& L. Arneodo 2017. Wildlife disturbance and winter recreational activities in Alpine protected areas: recommendations for successful management. eco.mont - Journal on Protected Mountain Areas Research and Management 2(9): 66-73.

David, G.C.L., B.P. Bledsoe, D.M. Merritt \& E. Wohl 2009. The impacts of ski slope development on stream channel morphology in the White River National Forest, Colorado, USA. Geomorphology 103: 375-388.

Delgado, R., M. Sánchez-Maranón, J.M. MartinGarcia, V. Aranda, F. Serrano-Bernardo \& J.L. Rosua 2007. Impact of ski pistes on soil properties: a case study from a mountainous area in the Mediterranean region. Soil Use and Management 23(3): 269-277.

Deutscher Alpenverein 2014. Grundsatzprogramm zum Schutz, und zur nachbaltigen Entwicklung des Alpen- raumessowie zum umweltgerechten Bergsport. München. [In German]

Dickson, T.J. \& P. Faulks 2007. Exploring overseas snowsport participation by Australian skiers and snowboarders. Tourism Review 62(3/4): 7-14.

Dorocki, S., P. Raźniak \& D. Obirek 2014. Rozwój infrastruktury narciarskiej w Polsce i na terenie Podhala w świetle badań ankietowych. Prace Komisji Geografii Przemystu Polskiego Towaraystwa Geograficznego: 28-77. [In Polish]

Dudley, N. (ed.) 2008. Guidelines for Applying Protected Area Management Categories. Gland, Switzerland: IUCN

Dupuis, L. 2004. Winter Tourism in Protected Pleasure Peripheries. Time-Space Use among CrossCountry Skiers in Abisko (Sweden) and Vercors (France). Scandinavian Journal of Hospitality and Tourism. 4(2): 129-153

Eagles, P.F., S.F. McCool \& C.D. Haynes 2002. Sustainable Tourism in Protected Areas. Guidelines for Planning and Management. World Commission on Protected Areas, IUCN, Best Practice Protected Area Guidelines Series 8.

Fahey, B. \& K. Wardle 1998. Likely impacts of snow grooming and related activities in the West Otago ski fields. Wellington, N.Z.: Dept. of Conservation.

Fahey, B., K. Wardle \& P. Weir 1999. Environmental effects associated with snow grooming and skiing at Treble Cone Ski Field. Part 2. Snow properties on groomed and non-groomed slopes. Science for Conservation 120B: 49-62.

Falarz, M. 2002. Klimatyczne przyczyny zmian i wieloletniej zmienności występowania pokrywy śnieżnej w polskich Tatrach. Przeglad Geograficzny 74 (1): 83-107. [In Polish]

Flagestad, A. \& Ch. Hope 2001. Strategic success in winter sports destinations: a sustainable value creation perspective. Tourism Management 22: 445-461

Gilbert, D. \& S. Hudson 2000. Tourism demands constraints: A skiing participation. Annals of Tourism Research 27(4): 906-925.

Guzik, M., P. Skawiński \& P. Wężyk 2002. Oddziaływanie narciarstwa zjazdowego na szatę roślinną doliny Goryczkowej w Tatrach. In: Partyka, J. (ed.), Użytkowanie turystyczne Parków Narodowych. Ruch turystyczny - zagospodarowanie - konflik.ty - zagrożenia: 723732. Ojców. [In Polish]

Havrlant, J. 2011. Kierunki i bariery modernizacji ośrodków sportów zimowych w czeskim regionie turystycznym „Beskidy”. Prace Geograficzne 125: 77-93. [In Polish]

Hennessy, K.J., P.H. Whetton, K. Walsh, I.N. Smith, J.M. Bathols, M. Hutchinson \& J. Sharples 2008. Climate change effects on snow conditions in mainland Australia and adaptation at ski resorts through snowmaking. Climate Research 35: 255-270.

Holden, A. 2000. Winter Tourism and the Environment in Conflict: The Case of Cairngorm, Scotland. International Journal of Tourism Research 2: 247-260. 
Holko, L., S. Bičárová, Z. Kostka \& A. Pribullová 2009. Climatic conditions and development of skiing in the Skalnata dolina valley, the High Tatra Mountains. In: Pribullová, A. \& S. Bičárová (eds.), Sustainable Development and Bioclimate, Reviewed Conference Proceedings: 24-25.

Hrčková, L. \& Z. Holubová. 2011. Hodnotenie zmeny krajinných štruktúr a stupňa antropickej influencie vo vybraných rekreačno-športových areáloch $\mathrm{v}$ oblasti Vysokých Tatier. Acta Facultatis Ecologiae, Journal of Faculty of Ecology and Environmental Sciences Technical University in Zvolen 24-25: 37-45. [n Slovak]

Imoos, U. \& M. Hunziker 2015. The effect of communicative and on-site measures on the behaviour of winter sports participants within protected mountain areas - results of a field experiment. eco.mont-Journal on Protected Mountain Areas Research and Management 7(1): 17-25.

IUCN 2016. Red List of Ecosystems. Available at: https://www.iucn.org/about/union/commissions/ cem/cem_work/tg_red_list/ (accessed: 28/03/2016)

Jančura, P., B. Beláček., I. Bohálová \& M. Slámová 2009a. Scientific significance of visualisation methods for expression of selected attributes of landscape character of the High Tatra Mountains. Landform Analysis 10: 44-49.

Jančura, P., M. Slámová, L. Hrčková \& B. Beláček 2009b. Downhill courses as significant landscape structure of the High Tatras Mts., Slovakia. Landform Analysis 11: 33-39.

Jodłowski, M. 2019. Udostęnianie górskich parkón narodowych w Europie. Instytut Geografii i Gospodarki Przestrzennej, Uniwersytet Jagielloński, Kraków. [In Polish]

Kasprowy Wierch 2017a. Cable-car data. Available at: http://www.pkl.pl/kasprowy-wierch/koleje-i-wyciagi.html (accessed: 19/04/2018). [In Polish]

Kasprowy Wierch 2017b. Ski-slope data. Available at: http:/ / www.pkl.pl/kasprowy-wierch/trasy-narciarskie.html (accessed: 02/12/2017). [In Polish]

Kern, C.L. 2006. Demarketing as a Tool for Managing Visitor Demand in National Parks - An Australian Case Study. University of Canberra.

Koenig, U. \& B. Abegg 1997. Impacts of Climate Change on Winter Tourism in the Swiss Alps. Journal of Sustainable Tourism 5(1): 46-58.

Konieczniak, J. 2010. Encyklopedia schronisk tatrzanskich. Oficyna Wydawnicza „Wierchy” Centralnego Ośrodka Turystyki Górskiej PT'TK. Kraków. [In Polish]

Koniorczyk, G. \& J. Wiechoczek 2014. Demarketing miejsc - koncepcja, narzędzia i obszary zastosowania. Marketing $i$ Rynek 5: 11-20. [In Polish]

Konu, H., T. Laukkanen \& R. Komppula 2011. Using ski destination choice criteria to segment Finnish ski resort customers. Tourism Management 32: 10961105.

Kot, M. 2010. Analiza potencjalnych skutków przyrodniczych sztucznego śnieżenia tras narciarskich na Kasprowym Wierchu. In: Krzan, Z. (ed.), Prayroda Tatrzańskiego Parku Narodowego a człowiek. Nauka a zarzadzenie obszarem Tatr $i$ ich otoczeniem 3. TPN Zakopane: 41-44. [In Polish]

Krzan, Z., P. Skawiński \& M. Kot 2002. Dynamika grubości pokrywy śnieżnej terenów narciarskich Kasprowego Wierchu w latach 1992-2000. In: Borowiec, W., A. Kotarba, A. Kownacki, Z. Krzan \& Z. Mirek (eds.), Przemiany środowiska prayrodniczego Tatr: 423-427. Kraków - Zakopane. [In Polish]

Krzesiwo, K. 2014. Rozwój i funkecjonowanie stacji narciarskich $w$ polskich Karpatach. Kraków. [In Polish]

Krzesiwo, K. 2015. Rozwój turystyki narciarskiej w świetle idei zrównoważonego rozwoju - stan badań. Prace geograficzne 141: 117-140. [In Polish]

Krzesiwo, K. \& M. Mika. 2011. Ocena atrakcyjności turystycznej stacji narciarskich w świetle zagadnienia ich konkurencyjności - studium porównawcze Szczyrku i Białki Tatrzańskiej. Prace Geograficzne 125: 95110. [In Polish]

Laiolo, P. \& A. Rolando 2005. Forest bird diversity and ski-runs: a case of negative edge effect. Animal Conservation 7: 9-16.

Laszczyk, A.J., M. Wójcik \& T. Rokita 2007. Modernizacja napowietrznej kolei linowej „Kasprowy Wierch" w Zakopanem. Transport Miejski $i$ Regionalny 12: 26-30. [In Polish]

Madziková, A., R. Klamár, M. Rosič \& J. Kaňuk 2011. Główne kierunki i problemy rozwoju turystyki narciarskiej w Republice Słowackiej. Prace Geograficzne 125: 111-128. [In Polish]

Mayer, M. \& I. Mose 2017. The opportunity costs of worthless land: The nexus between national parks and glacier ski resorts in the Alps. eco.mont - Journal on Protected Mountain Areas Research and Management 9(special issue): $35-45$.

Mika, M. 2000. Turystyka jako czynnik przemian środowiska przyrodniczego - stan badań. In: Domański, B. (ed.), Prace geografične, Studia nad rozwojem lokalnym i regionalnym 106: 73-98. [In Polish]

Mirek, Z. 1996. Antropogeniczne zagrożenia i przekształcenia środowiska przyrodniczego. In: Mirek, Z., Z. Głowaciński, K. Klimek \& H. Piękoś-Mirkowa (eds.), Pryyroda Tatrzańskiego Parku Narodowego: 595617. Zakopane, Kraków. [In Polish]

Morrison, C. \& C. Pickering 2013. Limits to Climate Change Adaptation: Case Study of the Australian Alps. Geographical Research 51(1): 11-25.

Muntág, S. 2007. Najkrajšie vrchy. Bratysława. [In Slovak]

Negro, M., M. Isaia, C. Palestrini \& A. Rolando 2009. The impact of forest ski-pistes on diversity of ground-dwelling arthropods and small mammals in the Alps. Biodiversity Conservation 18: 2799-2821.

Nowacki, M. 2016. Porównanie efektywności polskich, czeskich i słowackich ośrodków narciarskich za pomoca metody cen hedonistycznych. Rozprawy Naukowe Akademii Wychowania Fiaycznego we Wrockawiu 54: 60-69. [In Polish] 
Pichler-Koban, C. \& M. Jungmeier 2017. Alpine parks between yesterday and tomorrow - a conceptual history of Alpine national parks via tourism in charismatic parks in Austria, Germany and Switzerland. eco. mont - Journal on Protected Mountain Areas Research 9(special issue): 17-29.

Portal Samorządowy 2017. Kolejka na Kasprowy Wierch w polskich rękach? Zarząd powiatu tatrzańskiego złożył ofertę kupna PKL. Available at: https://www.portalsamorzadowy.pl/prawo-i-finanse/ kolejka-na-kasprowy-wierch-w-polskich-rekachzarzad-powiatu-tatrzanskiego-zlozyl-oferte-kupnapkl,96704.html (accessed: 19/12/2019). [In Polish]

Portal Tatrzański 2019. Nowy projekt budowy kolejki łączącej Hrebienok z Tatrzańską Łomnicą. Available at: http://portaltatrzanski.pl/aktualnosci/ nowy-projekt-budowy-kolejki-laczacej-hrebienok-ztatrzanska-lomnica,410 (accessed: 02/12/2019). [In Polish]

Pribullová, A., J. Pecho \& S. Bičárová 2009. Analysis of snow cover at selected meteorological stations in the High Tatra Mountains. In: Pribullová, A. \& S. Bičárová (eds.), Sustainable Development and Bioclimate, Reviewed Conference Proceedings: 56-57

Pröbstl-Haider, U., W. Haider \& N. Mostegl 2016. Skiing unlimited? Acceptance of resort extension by skiers in Tyrol/Austria. In: Vasiljević, Đ., M. Vujičić, L. Lazić \& V. Stojanović (eds.), $8^{\text {th }}$ International Conference on Monitoring and Management of Visitors in Recreational and Protected Areas, September: 297-299. Novi Sad.

Pütz, M., D. Gallati, S. Kytzia, H. Elsasser, C. Lardelli, M. Teich, F. Waltert \& C. Rixen 2011. Winter Tourism, Climate Change, and Snowmaking in the Swiss Alps: Tourists' Attitudes and Regional Economic Impacts. Mountain Research and Development 31(4): 357-362.

Rączkowska, Z. \& A. Kozłowska 2010. Wpływ turystyki na rzeźbę i roślinność przy ścieżkach w otoczeniu Kasprowego Wierchu. In: Krzan, Z. (ed.), Prsyroda Tatrzańskiego Parku Narodowego a cztowiek. Nauka a zarzadzenie obszarem Tatr i ich otoczeniem 3: 21-28. Zakopane. [In Polish]

Ries, J.B. 1996. Landscape Damage by Skiing at the Schauinsland in the Black Forest, Germany. Mountain Research and Development 16(1): 27-40.

Ristić, R., M. Kasanin-Grubin, B. Radić, Z. Nikić \& N. Vasiljevic 2012. Land Degradation at the Stara Planina Ski Resort. Environmental Management 49: 580592.

Rixen, C., M. Freppaz, V. Stoeckli, C. Huovinen, K. Huovinen \& S. Wipf 2008. Altered snow density and chemistry change soil nitrogen mineralization and plant growth. Arctic, Antarctic, and Alpine Research 40: 568-575.

Rixen, C. \& A. Rolando (ed.) 2013. The Impacts of Skiing and Related Winter Recreational Activities on Mountain Environments.

Rixen, C., V. Stoeckli \& W. Ammann 2003. Does artificial show production affect soil and vegetation of ski pistes? A review. Perspectives in Plant Ecology Evolution and Systematics 5: 219-230.

Rixen, C., M. Teich, C. Lardelli, D. Gallati, M. Pohl, M. Pütz \& P. Bebi 2011. Winter Tourism and Climate Change in the Alps: An Assessment of Resource Consumption, Snow Reliability, and Future Snowmaking Potential. Mountain Research and Development 31(3): 229-236.

Rolando, A., E. Caprio, E. Rinaldi \& I. Ellena 2007. The impact of high-altitude ski-runs on alpine grassland bird communities. Journal of Applied Ecology 44: 210-219.

Roux-Fouillet, P., S. Wipf \& C. Rixen 2011. Longterm impacts of ski piste management on alpine vegetation and soils. Journal of Applied Ecology 48: 906-915.

Scott, D., G. McBoyle \& B. Mills 2003. Climate change and the skiing industry in southern Ontario (Canada): exploring the importance of snowmaking as a technical adaptation. Climate Research 23: 171-181.

Skawiński, P. 2005. Ochrona i udostępnianie Tatrzańskiego Parku Narodowego; stan obecny i wizja przyszłości. In: Krzan, Z. (ed.), Przyroda Tatrzanskiego Parku Narodowego a człowiek. Tatrzański Park Narodowy na tle innych górskich terenów chronionych 3: 25-28. Zakopane. [In Polish]

Spenceley, A., J. Kohl, S. McArthur, P. Myles, M. Notarianni, D. Paleczny, C. Pickering \& G.L. Worboys 2015. Visitor Management. In: Worboys, G.L., M. Lockwood, A. Kothari, S. Feary \& I. Pulsford (eds.), Protected Area Governance and Management. 715-750. Canberra.

Steiger, R. 2012. Scenarios for skiing tourism in Austria: integrating demographics with an analysis of climate change. Journal of Sustainable Tourism 20(6): 867-882.

Steiger, R. \& M. Mayer 2008. Snowmaking and Climate Change. Future Options for Snow Production in Tyrolean Ski Resorts. Mountain Research and Development 28(3/4): 292-298.

Sterl, P., R. Eder \& A. Arnberger 2010. Exploring factors influencing the attitude of ski tourers towards the ski touring management measures of the Gesäuse National Park. eco.mont - Journal on Protected Mountain Areas Research and Management 2(1): 31-38.

Szczerbińska, A. \& J. Pociask-Karteczka 2015. Sezon narciarski na Kasprowym Wierchu - tendencje i zmienność. In: Chrobak A. \& A. Kotarba (eds.), Nauka Tatrom, Vol. I, Nauki o Ziemi, Materialy V Konferencji Prayroda Tatrzanskiego Parku Narodowego a Człowiek, "Prayroda Tatrzańskiego Parku Narodowego a człowiek": 170-176. Zakopane. [In Polish]

Šturcel, M. \& J. Švajda 2005. Turystyka w wysokogórskim środowisku Tatr Słowackich. Návštevnost' vysokohorského prostredia slovenských Tatier. In: Ladygin, Z. \& B. Chovancová (eds.), Monitoring ruchu turystycznego w Tatrach. Monitoring návstevnosti Tatier. TPN. Zakopane: 37-42. [In Polish and Slovak]

Švajda, J. 2006. IUCN sa zaujimala o stav riešenia šiestich odporúčani z misie zástupcov IUCN v 
TANAP-e. Chranene uzemia Slovenska 68: 31-36. [In Slovak]

Švajda, J. 2009. Monitoring a manažment návštevnosti v modelovom územi Mengusovskej doliny (TANAP/BR Tatry). Chranene uremia Slovenska 78: 31-36. [In Slovak]

Taczanowska, K., M. Bielański, J. Hibner, M. Jodłowski \& T. Zwijacz-Kozica 2019. Winter tourism management and challenges in the Tatra National Park. In: Pröbstl-Haider, U., H. Richins \& S. Türk (eds.), Winter Tourism: Trends and Challenges. CAB International: 246-256.

TANAP 2019. Sprievodca pre Tatranský národný park. Available at: https://www.tanap.org/ (accessed: 01/12/2019). [In Slovak]

Tatra MAB 2019. Międzynarodowy Program „Człowiek i Biosfera”. Available at: https://tpn.pl/ poznaj/mab (accessed: 01/12/2019). [In Polish]

Tatrzański Park Narodowy 2018. Sprawozdanie z działalności Tatrzańskiego Parku Narodowego za rok 2018; 1-157. Unpublished materials TPN. [In Polish]

Thiel, D., S. Jenni-Eiermann, V. Braunisch, R. Palme \& L. Jenni 2008. Ski tourism affects habitat use and evokes a physiological stress response in capercaillie Tetrao urogallus: a new methodological approach. Journal of Applied Ecology 45(3): 845-853.

Thompson, I.B. 1999. Sustainable rural development in the context of a high mountain national park: The parc national de la Vanoise, France. Scottish Geographical Journal 115(4): 297-318.

Titus, J.H., S. Tsuyuzaki 1999. Ski slope vegetation of Mount Hood, Oregon, USA. Arctic, Antarctic, and Alpine Research 13: 97-104.

TPN 2018. Hokus Krokus. Nie czarujmy się, krokusy same się nie ochronią. Available at: https://tpn.pl/nowosci/hokus-krokus (accessed: 06/04/2020). [In Polish]

TPN 2019. Tatrzański Park Narodowy. Available at: https://tpn.pl/poznaj (accessed: 01/12/2019). [In Polish]

TPN Statistic 2019. Tatrzański Park Narodowy Statystyka. Available at: https://tpn.pl/zwiedzaj/turystyka/statystyka (accessed: 01/12/2019). [In Polish]

Tsuyuzaki, S. 1995. Ski slope vegetation in central Honshu, Japan. Environmental Management 19(5): 773 777.

Tsuyuzaki, S. 2002. Vegetation development patterns on ski slopes in lowland Hokkaido, northern Japan. Biological Conservation 108(2): 239-246.

Tylek, P. 2009. Prawno-ekologiczne uwarunkowania rozwoju narciarstwa na terenie Tatrzańskiego Parku Narodowego. Zeszyty Naukowe No 806 Uniwersytetu Ekonomicznego w Krakowie: 141-156. [In Polish]

Ustawa 2004. Ustawa z dnia 16 kwietnia 2004 r. o ochronie przyrody. Sejm of the Republic of Poland. Dz. U. 2004, no 92, poz. 880. [In Polish]

Ustawa 2008. Ustawa z dnia 3 października 2008 r. o udostępnianiu informacji o środowisku i jego ochronie, udziale społeczeństwa w ochronie środowiska oraz o ocenach oddziaływania na środowisko. Sejm of the Republic of Poland. Dz. U. 2008, no 199, poz. 1227. IIn Polish]

Vanham, D., E. Fleischhacker \& W. Rauch 2009. Impact of snowmaking on alpine water resources management under present and climate change conditions. Water Science \& Technology 59(9): 1793-1801.

Vysoke Tatry 2017a. Cable-car data. Available at: https://www.vt.sk/aktualny-stav-lanoviek-a-zjazdoviek/ (accessed: 02/12/2017)

Vysoke Tatry 2017b. Ski-slope data. Available at: https://www.vt.sk/hory/lyzovacka/mapy/ (accessed: 02/12/2017)

Watson, A. \& R. Moss 2004. Impacts of ski-development on ptarmigan (Lagopus mutus) at Cairn Gorm, Scotland. Biological Conservation 116: 267-275.

Wearing, S., D. Archer \& S. Beeton 2007. The Sustainable Marketing of Tourism in Protected Areas: Moving Forward. CRC for Sustainable Tourism Pty Ltd, Gold Coast. Queensland, Australia.

Wearing, S. 2008. National Parks, Tourism and Marketing. Australasian Parks and Leisure 11(4): 29-33.

Wipf, S., C. Rixen, M. Fischer, B. Schmid \& V. Stoeckli 2005. Effects of ski piste preparation on alpine vegetation. Journal of Applied Ecology 42(2): 306316.

Witkowski, Z., A. Mroczka, P. Adamski, M. Bielański \& A. Kolasińska 2010. Nielegalna dyspersja turystów - problem parków narodowych i rezerwatów przyrody w Polsce. Folia Turistica 22: 35-65. [In Polish]

Zwijacz-Kozica, T. 2008. Black grouse leks in the central part of the Tatra National Park and their potential threats from ski tourism. Conference: I Miedzynarodowa Konferencja Ochrona Kurakón Leśnych: 144 -151.

Zwijacz-Kozica, T., N. Selva, J. Barja., G. Silvan, L. Martinez-Fernandez, J. Illera \& M. Jodłowski 2013. Concentration of fecal cortisol metabolites in chamois in relation to tourist pressure in Tatra National Park (South Poland). Acta Theriologica 58(2): 215-222.

Żemła, M. 2008. The product quality of Polish ski-resorts: A case study of Silesian skiers' requirements, satisfaction and complaints. Tourism 56(1): $41-58$.

\section{Authors}

Joanna Hibner - corresponding author

is an assistant at the Institute of Geography and Spatial Management, Jagiellonian University, Krakow, Poland. Her main research interests are the monitoring and management of visitors in protected areas, mountain protected areas, and landscape perception. E-mail: joanna.hibner@uj.edu.pl

\section{Jarosław Balon}

is an assistant professor at the Institute of Geography and Spatial Management, Jagiellonian University, Krakow, Poland. His main research interests are the structure and function of the high-mountain environ- 
ment, and the stability of the natural environment of the mountains.

\section{Miłosz Jodłowski}

is a geographer, currently holds a position of president of Access \& Conservation Commission in Polish Mountaineering Association. His main research interests are: high-mountain geoecol-ogy as well as tourism management and recreational use in protected areas.
Szymon Ciapała

Head of the Ecology Faculty, University of Physical Education in Krakow. His scientific interests focus on tourist impacts on nature, and methods of tree-ring dating to assess the impacts of tourism. University of Physical Education in Krakow, Ecology Faculty, Cracow, Poland. 